\title{
Retraction Note to: Quality of life in endometrial cancer survivors: single institution experience in Slovakia
}

Erik Lajtman* (1)

\section{Retraction to: Health and Quality of Life Outcomes (2020) 18:221 https://doi.org/10.1186/s12955-020- 01474-1}

The Editor-in-Chief has retracted this article because it has been previously published by the same author [1]. This article is therefore redundant.

The author has not responded to correspondence regarding this retraction.

\section{Reference}

1. Lajtman E. Quality of life in endometrial cancer survivors: a 10-year experience from a cancer center in Slovakia. Int J Hematol Oncol. 2019;4:29. https://doi.org/10.4999/uhod.193477.

\section{Publisher's Note}

Springer Nature remains neutral with regard to jurisdictional claims in published maps and institutional affiliations.

Published online: 01 April 2021

The original article can be found online at https://doi.org/10.1186/s12955020-01474-1.

*Correspondence: lajtmanerik@gmail.com

Gynecology and Obstetrics Department, Faculty Hospital Nitra and Constantine The Philosopher University in Nitra, Spitalska 6, 949

01 Nitra, Slovakia permits use, sharing, adaptation, distribution and reproduction in any medium or format, as long as you give appropriate credit to the original author(s) and the source, provide a link to the Creative Commons licence, and indicate if changes were made. The images or other third party material in this article are included in the article's Creative Commons licence, unless indicated otherwise in a credit line to the material. If material is not included in the article's Creative Commons licence and your intended use is not permitted by statutory regulation or exceeds the permitted use, you will need to obtain permission directly from the copyright holder. To view a copy of this licence, visit http://creativecommons.org/licenses/by/4.0/. The Creative Commons Public Domain Dedication waiver (http://creativeco mmons.org/publicdomain/zero/1.0/) applies to the data made available in this article, unless otherwise stated in a credit line to the data. 